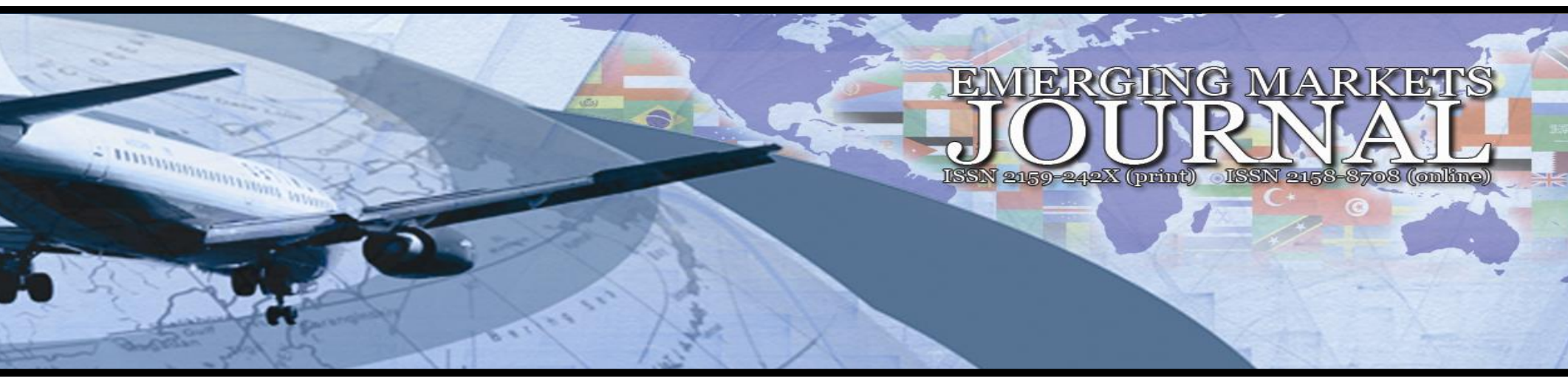

\title{
Global Online Entrepreneurship and the Impact of Innovation on Brands
}

\section{Ipek Krom}

Assistant Professor, Beykent University, | e-mail: ipekkrom@ outlook.com

Volume 5 No 2 (2015) ｜ ISSN 2158-8708 (online) | DOI 10.5195/emaj.2015.90 | http://emaj.pitt.edu |

\section{Abstract}

The purpose of this paper is to evaluate the significance of innovation driven online entrepreneurship as well as the impact of innovation on brand trust, customer satisfaction and brand loyalty in the extent of service innovations. Global online entrepreneurship was explored on a theoretical basis and correlation as well as regression analyses were used in order to evaluate the impact of the innovations of Google on brand trust, customer satisfaction and brand loyalty. Furthermore, correlation and regression analyses were used in order to find out the relationship between brand loyalty and brand trust as well as the relationship between brand loyalty and customer relationship in the extent of service industry. The results show a direct and positive relationship between innovation and brand loyalty, a direct and positive relationship between innovation and brand trust and a direct and positive relationship between innovation and customer satisfaction. Furthermore, according to the research findings brand trust and customer satisfaction have a direct and positive relationship with brand loyalty. This research is limited to Google users, since it is the most popular search engine worldwide. In this article the impact of innovation on brand trust, customer satisfaction and brand loyalty was evaluated. For future research, the impact of innovation on other variables of brand loyalty can be studied. The findings of this study inform the readers about the impact of brand trust, customer satisfaction and brand loyalty on innovation in the extent of service innovations driven by global online entrepreneurship.

Keywords: Brand Loyalty, Brand Trust, Customer Satisfaction, Global Online Entrepreneurship, Innovation, Service Innovation $(\mathrm{cc}) \mathrm{EY}$

New articles in this journal are licensed under a Creative Commons Attribution 3.0 United States License.

\section{UILSS D-Serk}

This journal is published by the University Library System of the University of Pittsburgh as part of its D-Scribe Digital Publishing Program, and is cosponsored by the University of Pittsburgh Press. 


\section{Global online entrepreneurship and the impact of innovation on brands}

\section{Ipek Krom}

\section{Introduction}

Entrepreneurship is the dynamic process of bringing resources, labor, materials, and other assets into combinations that make their value greater than before. That introduces changes, innovations, as well as a new order (Hisrich, Peters, and Shepherd, 2005). According to Schumpeter, all truly important changes in the economy are set off by the entrepreneur. An entrepreneur is an innovator creating new products/services, introducing new methods of production, new markets and new organizational models (Schumpeter, 1934).

However, considering the advances in information communication technology (ICT), the fast moving characteristics of internet business and the different demographic and geographic background of the users, internet entrepreneurs are faced with a very unstable, uncertain, challenging and highly competitive environment.

In terms of opportunity creation and market change, the internet environment can thus be described as change based and fast moving. Even though this state offers many market opportunities, it is also characterized by continuous turmoil since it includes the participation of users from all demographic and geographical backgrounds. Furthermore as new businesses and new business models develop, new online ways of generating income are searched, and as a result new social activities as well as new groups of people with common interests emerge. As these multiple participatory items occur, change, evolve and adapt, they each have the potential to cause a ripple effect since they have the potential to change the behavior of the users (Zhao, 2008).

On the other hand, global online entrepreneurs (GOE) or in other words Born Global enterprises like Google, Ebay and Amazon successfully keep up with this pace and what is more, they bring new standards to the industry.

Google has had and still has a very strong impact on ebusiness activities of existing international businesses. Virtual enterprises also use Google and its applications widely. Today, Google is the most popular global search engine occupying 53.74 percent of the global search engine market (Marketshare Statistics for Internet Technologies, 2014). Starting as a predominantly online bookstore in 1994, today Amazon serves 209 million customers. 68.6 percent of smartphone users have an Amazon application. Today, 70.000 books are available on Amazon's match program in various areas of interest. Enabling the users to buy and sell in nearly every country on earth, Ebay on the other hand has more than 120 million users globally (Smith, 2014).

When compared with the owners of ventures that are not fully dedicated to electronic commerce, distinctive innovative behaviors appear to characterize the emerging group of internet entrepreneurs. Although they are not different from other enterprises, the internet entrepreneurs operate in a universe of transforming change. As pioneers of the new networked society, they are both defining and learning new ways of doing business (Morino, 1999).

Researchers divide the innovation generation phase into five stages: Idea generation, project definition, problemsolving, design and development, and marketing or commercialization (Gopalakrishnan and Damanpour, 1997).

Carrier, Raymond and Eltaif (2004) state that, idea generation amongst internet entrepreneurs is different from the traditional idea generation of other enterprises. Internet entrepreneurs are more likely to search the market for opportunities, rather than creating a new product or service and then test its market feasibility. Furthermore, internet entrepreneurs initially search the market or analyze the need and generate ideas or solutions in response.

In addition Kickul and Gundry (2002) describe internet firms that emphasize information and rapid response to change as probably the best positioned enterprises for recognizing and identifying new opportunities.

As a result of globalization, the demands of the customers are moving towards innovation; and because of the global competition, more and more customers are opting to adopt or choose new products. Therefore, new technologies are trying to be developed to draw the attention of the customers, and create customer satisfaction and brand loyalty as the advancement in technology enables the companies to respond to the needs and demands of the customers better (Schickler, 1994).

According to Hausman (1995), who researches customer satisfaction and innovation, innovation has an important role in customer happiness and customer satisfaction, since the firm takes innovative actions according to the complaints received from the customer.

Furthermore, according to the research carried by Naveed, Akhtar, Cheema (2013), there is an important connection between innovation, customer satisfaction and brand loyalty. When a firm produces an innovative product, the satisfaction of the customers and their brand loyalty increases.

Brand trust and customer satisfaction are among the important variables of brand loyalty. According to Upamannyu, Gulati and Mathur (2014), and Turker and Turker (2013) brand trust has a significant positive impact on 
brand loyalty. Furthermore a variety of studies state that higher levels of customer satisfaction lead to greater customer loyalty (Anderson and Sullivan, 1993; Bearden and Teel, 1983; Bolton and Drew, 1991; Ghafoor et al. 2012). Several studies in the literature study the impact of innovation on customer satisfaction including Hussain, Munir, and Siddiqui (2002), Naveed, Akhtar, Cheema (2013), and Hausman (1995). According to all these studies, innovation has a direct and positive relationship with customer satisfaction and brand loyalty. However, this article will focus on the relationship between brand trust, customer satisfaction, brand loyalty and innovation in the extent of service innovations. In this article, the impact of innovation on the variables of brand trust, brand loyalty and customer satisfaction will be questioned within service innovation industry carrying a research on Google's innovative developments offered to the users.

\section{Literature Review}

\subsection{Global Online Entrepreneurship}

Morgan-Thomas and Reubar (2013, p.4), who have enlarged the international entrepreneurship definition of McDougall and Oviatt (2000, p.903), and adapted it to the online entrepreneurship field, define global online entrepreneurship (GOE) as "a combination of innovative, proactive and risk-seeking technologies to cross national boundaries and create value in organizations." The term GOE both refers to internationalizing companies that are internet based at birth as well as the e-business activities of existing international businesses. The e-business new ventures are new type of entrepreneur firms that owe their existence in the (ICT) field to the GOEs.

International entrepreneurship extends the impact of the roles and actions of entrepreneurs beyond their domestic frontiers and into the international markets and environments over time. As a result, the international entrepreneurs both have an impact on their own enterprise and the environment (Aldrich and Martinez, 2003).

Globalization of markets and technological advances in ICT are among the two environmental reasons for the early adoption of born globals (Knight and Cavusgil, 2004). Furthermore, the ICT technologies decrease the costs and risks for born globals to internationalize. However, the key factor for their widespread emergence and success is their internal environment. Generally, in spite of their constrained resources and inexperience, born-global companies, develop their competitive advantage from a combination of sources and theories including research and development, membership in the network (network theory), flexible responsiveness to the environment, and the learning organization theory (Jaw and Chang, 2006).

Among the important features of the antecedents of the GOEs are entrepreneurial orientation, risk taking, the identification of opportunities, market orientation, networks and social capital (Colton, Roth, and Bearden 2010; Houghton \& Winklhofer 2004; Mostafa, Wheeler and Jones 2006). In addition, the importance of open innovation and consumer relationships has recently been recognized (Bell and Loane, 2010).

\subsection{Service Innovation}

According to the Oslo Manual, which is internationally been recognized regarding the definition of innovation: "An innovation is the implementation of a new or significantly improved product (good or service), or process, a new marketing method, or a new organizational method in business practices, workplace organization or external relations (OECD and Eurostat, 2005, p.46)."

As a driver of growth and structural change across the whole economy, service innovation enables the economy to become more productive and provides fuel for innovation in other industries. As it is in the Google case, service innovation even has the potential to create new growth poles and lead markets that have a macro-economic impact.

By transforming the way we live, do business and interact with each other, service innovation can bring about structural and economic change in our societies (European Union, 2012). On the other hand, the customers and the changes in customer needs are of critical importance within this innovation chain since the customers are an important driver of innovation, a major influence in the innovation process within companies and the most important factor determining whether a product or service is accepted in the market (Business Decisions Limited, 2003).

Through service innovation, new or significantly improved service concepts are introduced into the market. These service concepts of service companies or manufacturing companies comprise service infrastructure, customer processing, business models, commercialization (sales, marketing, delivery), service productivity and hybrid forms of innovation serving several user groups in different ways simultaneously (European Union, 2012).

Regarded as positive developments by the customers, through service innovation, the customers develop of a positive perception towards the company (Karaca, 2009).

\subsection{Brand Loyalty}

Oliver defines brand loyalty as "A deeply held commitment to re-buy or repatronize a preferred product or service consistently in the future, causing repetitive same brand or same brand-set purchasing, despite situational influences or marketing efforts" (Oliver, 1999, p.34). Information about the brand plays a key role in the product choice of the customers. When the consumers perceive distinctive features in a brand and get impressed, their brand loyalty towards this brand increases. The basic feature of a brand is the fact that it creates a loyal consumer (Uztug, 2003). 
Customers with brand loyalty are a group consumers who are loyal to the brand, who think that the rival products or services do not satisfy them like the chosen brand and who constantly purchase the brand. This consumer group is the target audience, which brings the highest income to the firms and should definitely need to be preserved and even get widened. Upon brand building step, customer satisfaction has a key role in creating brand loyalty. If the consumers do not get pleased with the product, then their brand loyalty does not develop and they begin to look for new alternatives. For these reasons, the concept of brand loyalty is evaluated within the concept of brand equity (Aaker, 1991).

Brand loyalty is one of the basic factors that constitute the brand equity and it develops through the consumers trust towards the brand. The most important feature of a strong brand is that it has a loyal mass of consumers.

While acquiring new customers is a hard and expensive process, holding on to existing customers is a relatively easy and inexpensive one. High brand loyalty means a high market share and steady revenue that is acquired through repetitive purchases. What is more, a brand with a high brand loyalty can constitute an obstacle for products that are new to the market and can prevent the increase in competition. Since loyal customers are less price sensitive, the firms can work with higher profit shares.

Today, all firms have the aim of creating a loyal customer portfolio. Every year, the thousands of new products that enter the market cause an increase in product costs and change costs and this creates a positive situation for the customers to hold on to the brands they know and trust. This evaluation is based on the inclination of the decrease in risk taking and conservatism. However, in such dynamic and unsteady market conditions, the question of how will the brand be able to turn this conservative attitude into its own advantage or how will it be able to direct the customers to itself prevails (Aydin, 2009).

\subsection{Brand Trust}

Brand loyalty, which develops through a brand's continuation in realizing its responsibilities, refers to the good intentions of a firm and to the fact that the firm will act in consideration of the customers' interests. (Doney and Cannon, 1997). According to Delgado (2003, p.11), brand trust is defined as the "Feeling of security held by the consumer in his/her interaction with the brand, that it is based on the perceptions that the brand is reliable and responsible for the interests and welfare of the consumer." Brand trust has two dimensions. Reliability, which has a technical or competencebased nature, is the first dimension of brand trust that comprises the ability and willingness of the firm to keep promises and satisfy the needs of the consumers. In relation to the interests and welfare of the consumers', the second dimension involves the attribution of good intentions to the brand. For instance, when unexpected problems with the product arise, the customers can still have good intentions regarding the brand if they hold brand trust (Delgado et al. 2003; Doney and Cannon, 1997). Brand trust comprises concepts like product quality, meeting the needs of the consumers', support, consistency and honesty. The in depth relationship between the firm and the customer increases the customers' potential of sharing their private and secret information with the brand. Later on, this information can be used in the development of products and services which the firms had not initially thought of producing or financing (Bozkurt, 2003). Brand trust enables the brands to build strong consumer relationships (Fournier, 1998; Urban, Sultan, and Qualls, 2000), and has a positive impact on brand loyalty (Lau and Lee, 1999).

\subsection{Customer Satisfaction}

Customer satisfaction is the way a person feels after comparing a product's perceived performance according to his or her expectations (Kotler and Armstrong, 1996). The concept of customer satisfaction extends beyond meeting the needs and expectations of customers. Customer satisfaction emerges with the evaluation of a product or service in terms of variables like quality and performance. According to this, customer satisfaction or dissatisfaction develops through a comparison of customers' expectations and perception. At the point where the advantages provided by the purchased product or service and the customer expectations meet, customer satisfaction emerges (Turk, 2005). In influencing customers' decisions in order for them to buy new products or services, three factors stand out as the most important: Awareness of new products and their benefits, quality and price compared to alternatives, as well as customer satisfaction among those who have tried the products or services (Business Decisions Limited, 2003). Critical to any product or service company, customer satisfaction is a strong predictor of customer retention, customer loyalty and product repurchase. According to research, a single unsatisfied customer can spoil five satisfied customers (Sreenivasulu and Rajasekhar, 2014).

\section{Hypothesis}

On the basis of literature review and considering the critical role innovation plays in service industry in ICT sector as well as the impact of brand trust and consumer satisfaction on brand loyalty, five hypothesis were developed. 


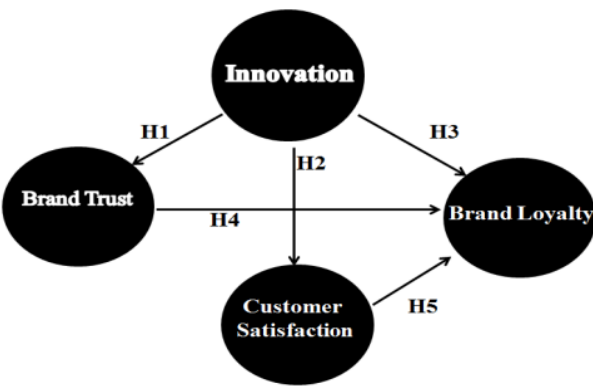

Figure 1. The Model of the Impact of Innovation on Brand Trust, Brand Loyalty and Customer Satisfaction

H1: Innovation has a direct and positive relationship with brand trust.

$\mathrm{H} 2$ : Innovation has a direct and positive relationship with customer satisfaction.

H3: Innovation has a direct and positive relationship with brand loyalty.

H4: Brand trust has a direct and positive relationship with brand loyalty.

H5: Customer satisfaction has a direct and positive relationship with brand loyalty.

\section{Research Methodology}

In order to conduct this study, quantitative methods were used. Research data were collected through a questionnaire and research was conducted on university students. People falling in the age group of 18 to 34 years were chosen for the study, since that is considered as the most information and communication technology oriented group. The research is limited to Google users, since Google is the most popular search engine globally. The research was conducted in T.C. Beykent University and Yildiz Technical University (YTU). The reason for the selection of these universities is to receive a sampling of students from different socioeconomic backgrounds, because T.C. Beykent University is a private university with public entities and YTU is a state university, and also because both universities highly support information communication technology applications. A total of 395 questionnaires were received showing a response rate of $\%$ 87.7. The demographics of the respondents are shown in Table 1.
TABLE 1

RESPONDENT'S DEMOGRAPHIC INFORMATION

\begin{tabular}{cccc} 
& Groups & Frequency(n) & Percentage (\%) \\
\hline \hline \multirow{4}{*}{ University } & Beykent & 219 & 55.4 \\
& YTU & 176 & 44.6 \\
& Total & 395 & 100.0 \\
& Male & 204 & 51.6 \\
\multirow{6}{*}{ Gender } & Female & 191 & 48.4 \\
& Total & 395 & 100.0 \\
& $17-21$ & 195 & 51.6 \\
& $22-24$ & 185 & 48.4 \\
& $25-34$ & 15 & 3.8 \\
& Total & 395 & 100.0 \\
\hline \hline
\end{tabular}

According to the survey results carried in this research, some examples of innovative developments of Google like android, autocomplete, gmail, internet balloons, google academic, google art project, google books, google driveless cars, google earth, google fiber, google glass, google maps, google now, google streetview, google translate, google TV, google voice search and universal search are known by students on the below listed ratios listed in table 2 .

TABLE 2

INNOVATIVE DEVELOPMENTS OF GOOGLE KNOWN BY STUDENTS

\begin{tabular}{lcc} 
Google's Innovations & Frequency & Percentage \\
\hline \hline Android & 308 & 78.0 \\
Autocomplete & 96 & 24.3 \\
Gmail & 373 & 94.4 \\
Internet Baloons & 50 & 12.7 \\
Google Academic & 98 & 24.8 \\
Google Art Project & 54 & 13.7 \\
Google Books & 152 & 38.5 \\
Google Driveless Cars & 59 & 14.9 \\
Google Earth & 325 & 82.3 \\
Google Fiber & 41 & 10.4 \\
Google Glass & 128 & 32.4 \\
Google Maps & 319 & 80.8 \\
Google Now & 21 & 5.3 \\
Google Streetview & 55 & 13.9 \\
Google Translate & 334 & 84.6 \\
Google TV & 93 & 23.5 \\
Google Voice Search & 184 & 46.6 \\
Universal Search & 163 & 41.3 \\
\hline \hline
\end{tabular}

Furthermore, among these innovative developments of Google, the ones that are used by students are android (\%59.7), autocomplete (\%16.7), gmail (\%87.1), google 
academics (\%14.2), google art project (\%4.6), google books $(\% 20.3)$, google earth (\%65.1), google maps (\%66.8), google now (\%4.1), google streetview (\%7.6), google translate (\%73.7), google voice search $(\% 23.8)$ and universal search (\%38.7). These innovative services that are actively used by participants also provide a basis for brand loyalty.

The research questionnaire was designed on 5 point Likert rating scale. $5=$ strongly agree, $4=$ agree, $3=$ neutral, $2=$ disagree, $1=$ strongly disagree. These questions were based on brand trust, brand loyalty, customer satisfaction and innovation. A new scale on brand trust was developed using the scales of Simsek and Noyan (2009), Caceres and Paparoidamis (2007) as a reference. Also, other new scales were developed on brand loyalty, customer satisfaction and innovation. The scale on brand loyalty was developed using the scale of Simsek and Noyan (2009), making an adaptation to the search engine field. The scale on customer satisfaction was developed adapting the scale of Lin and Wang (2006) to the search engine field. Finally, the scale on innovation was developed according to the Oslo Manual (OECD and Eurostat, 2005). The items in the scales were 18 in number.

The data were analyzed by the help of SPSS software. While comparing the quantitative data, the difference between two groups was tested using t-tests. Furthermore, correlation and regression techniques were used to analyze the received data. The correlation analysis showed the relationship between the variable innovation and the variables of brand trust, brand loyalty and customer satisfaction brand loyalty while regression analysis showed the strength of relationship between these variables. Innovation is treated as an independent variable; brand trust and customer satisfaction as moderating variables while brand loyalty as dependent variable. The research findings were evaluated in between $\% 95$ confidence interval and $\% 5$ meaningfulness level.

The reliability and validity of the scales were checked. The results show that, the scales are highly reliable.

The reliability of the brand trust scale was found as $\alpha=0.880$. At the end of the KMO and Barlett analysis for the brand trust scale, it was configured that $\mathrm{KMO}$ value is 0.869 and Barlett value is smaller than 0.05 and that the factor analysis could be applied. After the factor analysis, one factor was formed with a total variance of $\% 67.98$.

The reliability of the customer satisfaction scale was found as $\alpha=0.904$. After the KMO and Barlett analysis for the customer satisfaction scale, it was configured that KMO value is 0.751 and Barlett value is smaller than 0.05 and that the factor analysis could be applied. After the factor analysis, one factor was formed with a total variance of \% 83.96.

The reliability of the brand loyalty scale was found as $\alpha=0.882$. After the KMO and Barlett analysis for the customer satisfaction scale, it was configured that KMO value is 0.833 and Barlett value is smaller than 0.05 and that the factor analysis could be applied. After the factor analysis, one factor was formed with a total variance of $\% 74.24$.

Finally, the reliability of the innovation scale was found as $\alpha=0.884$. After the KMO and Barlett analysis that were conducted for innovation scale, it was configured that KMO value is 0.884 and Barlett value is smaller than 0.05 and that the factor analysis could be applied. After the factor analysis, one factor was formed with a total variance of $\% 63.61$.

The conducted analyses showed that the scales were all valid.

\section{Research Findings}

In this section, the research findings on innovation, brand trust, customer satisfaction and brand loyalty levels are described.

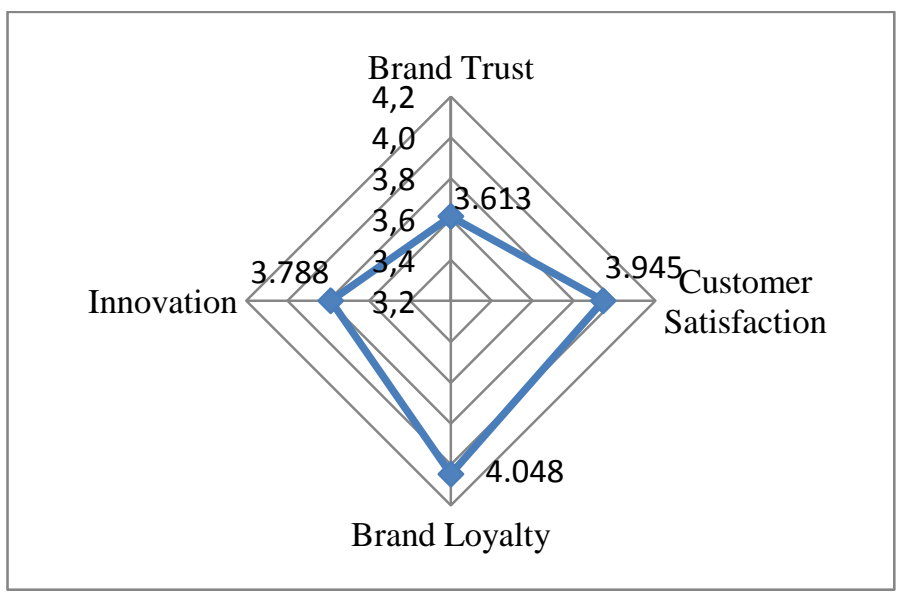

Figure 2. The Innovation, Brand Trust,

Customer Satisfaction and Brand Loyalty Levels of the Students

According to the research findings, the students who have participated in the research have a high level of brand trust $(3.613 \pm 0.829)$; a high level of customer satisfaction $(3.945 \pm$ $0.778)$; a high level of brand loyalty $(4.048 \pm 0.818)$ and a high level of innovation (3.788 \pm 0.735$)$.

TABLE 3

THE DIFFERENTIATION OF INNOVATION, BRAND TRUST, CUSTOMER SATISFACTION AND BRAND LOYALTY ACCORDING TO EACH UNIVERSITY

\begin{tabular}{llllllll} 
Groups & $\begin{array}{l}\text { Beykent } \\
\text { University } \\
(\mathbf{n = 2 1 9})\end{array}$ & \multicolumn{3}{l}{$\begin{array}{l}\text { YTU } \\
(\mathbf{n = 1 7 6})\end{array}$} & $\mathbf{t}$ & $\mathbf{p}$ \\
& Mean & SD & \multicolumn{2}{l}{ Mean } & SD & & \\
\hline \hline $\begin{array}{l}\text { Brand Trust } \\
\text { Customer }\end{array}$ & 3.659 & 0.848 & 3.555 & 0.803 & 1.250 & 0.212 \\
Satisfaction & 4.009 & 0.829 & 3.866 & 0.705 & 1.828 & 0.068 \\
Brand Loyalty & 4.097 & 0.826 & 3.986 & 0.807 & 1.345 & 0.180 \\
Innovation & 3.823 & 0.792 & 3.745 & 0.657 & 1.041 & 0.289 \\
\hline \hline
\end{tabular}


According to the t-tests that were conducted; the innovation, brand trust, customer satisfaction and brand loyalty levels do not have a meaningful difference according to the university variable. This shows us that, the students of both universities have equal access to information communication technologies.

\section{TABLE 4}

THE RELATIONSHIP BETWEEN INNOVATION, BRAND TRUST, CUSTOMER SATISFACTION AND BRAND LOYALTY

\begin{tabular}{|c|c|c|c|c|c|c|}
\hline & $\begin{array}{l}\text { Mea } \\
\text { n }\end{array}$ & SD & $\begin{array}{l}\text { Brand } \\
\text { Trust }\end{array}$ & $\begin{array}{l}\text { Customer } \\
\text { Satisfactio } \\
\text { n }\end{array}$ & $\begin{array}{l}\text { Brand } \\
\text { Loyalt } \\
\mathbf{y}\end{array}$ & $\begin{array}{l}\text { Innovatio } \\
\text { n }\end{array}$ \\
\hline $\begin{array}{l}\text { Brand } \\
\text { Trust }\end{array}$ & 3.613 & $\begin{array}{l}0.82 \\
9\end{array}$ & 1.000 & & & \\
\hline $\begin{array}{l}\text { Customer } \\
\text { Satisfactio } \\
\text { n }\end{array}$ & 3.945 & $\begin{array}{l}0.77 \\
8\end{array}$ & $\begin{array}{l}0.803 * \\
*\end{array}$ & 1.000 & & \\
\hline $\begin{array}{l}\text { Brand } \\
\text { Loyalty }\end{array}$ & 4.048 & $\begin{array}{l}0.81 \\
8\end{array}$ & $\begin{array}{l}0.666 * \\
*\end{array}$ & $0.754 * *$ & 1.000 & \\
\hline Innovation & 3.788 & $\begin{array}{l}0.73 \\
5\end{array}$ & $\begin{array}{l}0.687 * \\
*\end{array}$ & $0.719 * *$ & $\begin{array}{l}0.749 * \\
*\end{array}$ & 1.000 \\
\hline
\end{tabular}

According to the correlation analysis that was conducted, a statistically meaningful relationship exists between customer satisfaction and brand trust $(\mathrm{r}=0.803 ; \mathrm{p}=0.000<0.05)$. According to this finding, brand trust increases as customer satisfaction increases.

The relationship between brand loyalty and brand trust is also statistically meaningful $(\mathrm{r}=0.666 ; \mathrm{p}=0.000<0.05)$. According to this result, as brand trust increases, brand loyalty also increases.

According to the research findings, the relationship between brand loyalty and customer satisfaction is statistically meaningful $(r=0.754 ; p=0.000<0.05)$. According to this result, as customer satisfaction increases, brand loyalty also increases.

The relationship between innovation and brand trust is also statistically meaningful $(r=0.687 ; p=0.000<0.05)$. According to this result, as innovation increases, brand trust increases.

When the relationship between innovation and customer satisfaction was examined, the relationship was found as statistically meaningful $(\mathrm{r}=0.719 ; \mathrm{p}=0.00<0.05)$. According to this finding, as innovation increases, customer satisfaction also increases.

Finally, according to the correlation analysis that was carried out, the relationship between innovation and brand loyalty was found as meaningful $(\mathrm{r}=0.749 ; \mathrm{p}=0.000<0.05)$. According to this finding, as innovation increases, brand loyalty also increases.
TABLE 5

THE IMPACT OF BRAND TRUST ON BRAND LOYALTY

\begin{tabular}{llllllll}
$\begin{array}{l}\text { Dependen } \\
\mathbf{t} \\
\text { Variable }\end{array}$ & $\begin{array}{l}\text { Independe } \\
\text { nt Variable }\end{array}$ & $\mathbf{B}$ & $\mathbf{t}$ & $\mathbf{p}$ & $\mathbf{F}$ & $\begin{array}{l}\text { Mode } \\
\mathbf{1}(\mathbf{p})\end{array}$ & $\mathbf{R}^{2}$ \\
\hline \hline & Constant & $\begin{array}{l}1.67 \\
4\end{array}$ & 12.15 & 0.00 & 312.53 & 0.000 & 0.44 \\
Brand & & 9 & 0 & 2 & & 2 \\
Loyalty & Brand Trust & 0.65 & 17.67 & 0.00 & 312.53 & 0.000 & 0.44 \\
& & 7 & 9 & 0 & 2 & & 2 \\
\hline \hline
\end{tabular}

The regression analysis that was made to figure the relationship between brand trust and brand loyalty was found as statistically meaningful $(\mathrm{F}=312.532 ; \mathrm{p}=0.000<0.05)$. The explaining power of brand trust is very strong $\left(\mathrm{R}^{2}=0.442\right)$. According to this result, brand trust increases the level of brand loyalty $(\beta=0.657)$. Therefore, $\mathrm{H} 4$ hypothesis is confirmed.

TABLE 6

THE IMPACT OF CUSTOMER SATISFACTION ON BRAND LOYALTY

\begin{tabular}{lllllllll}
$\begin{array}{l}\text { Dependen } \\
\mathbf{t} \\
\text { Variable }\end{array}$ & $\begin{array}{l}\text { Independe } \\
\text { nt Variable }\end{array}$ & $\mathbf{B}$ & $\mathbf{t}$ & $\mathbf{p}$ & $\mathbf{F}$ & $\begin{array}{l}\text { Mode } \\
\mathbf{l}(\mathbf{p})\end{array}$ & $\mathbf{R}^{\mathbf{2}}$ \\
\hline \hline & & & & & & & & \\
Brand & Constant & 0.92 & 6.575 & 0.00 & & & \\
Loyalty & Customer & 0.79 & 22.76 & 0.00 & 1 & 0.000 & 8 \\
& satisfaction & 3 & 5 & 0 & & & 8 \\
\hline \hline
\end{tabular}

The regression analysis carried out in order to figure the relationship between customer satisfaction and brand loyalty was also found as statistically meaningful ( $\mathrm{F}=518.251$; $\mathrm{p}=0.000<0.05$ ). As the determinant of brand loyalty level, the explaining power of customer satisfaction is found as very strong $\left.\mathrm{R}^{2}=0.568\right)$. According to this result, customer satisfaction increases the brand loyalty level $(\beta=0,793)$, which confirms the H5 hypothesis. 
TABLE 7

THE IMPACT OF INNOVATION ON BRAND TRUST, CUSTOMER SATISFACTION AND BRAND LOYALTY

\begin{tabular}{|c|c|c|c|c|c|c|c|}
\hline $\begin{array}{c}\text { Dependent } \\
\text { variable }\end{array}$ & $\begin{array}{c}\text { Indepe } \\
\text { ndent } \\
\text { Variabl } \\
\text { e } \\
\end{array}$ & B & $\mathbf{t}$ & p & $\mathbf{F}$ & $\begin{array}{l}\text { Mo } \\
\text { del } \\
\text { (p) }\end{array}$ & $\mathbf{R}^{2}$ \\
\hline Brand Trust & $\begin{array}{c}\text { Constan } \\
\mathrm{t} \\
\text { Innovati } \\
\text { on }\end{array}$ & $\begin{array}{l}0.6 \\
76 \\
0.7 \\
75\end{array}$ & $\begin{array}{c}4.23 \\
9 \\
18.7 \\
50\end{array}$ & $\begin{array}{l}0.0 \\
00 \\
0.0 \\
00\end{array}$ & $\begin{array}{l}351 . \\
567\end{array}$ & $\begin{array}{c}0.00 \\
0\end{array}$ & $\begin{array}{l}0.4 \\
71\end{array}$ \\
\hline $\begin{array}{c}\text { Dependent } \\
\text { Variable }\end{array}$ & $\begin{array}{c}\text { Indepe } \\
\text { ndent } \\
\text { Variabl } \\
\text { e }\end{array}$ & $\overline{\mathbf{B}}$ & $\bar{t}$ & $\bar{p}$ & $\bar{F}$ & $\begin{array}{l}\text { Mo } \\
\text { del } \\
\text { (p) }\end{array}$ & $\overline{\mathbf{R}^{2}}$ \\
\hline $\begin{array}{c}\text { Customer } \\
\text { Satisfaction }\end{array}$ & $\begin{array}{c}\text { Constan } \\
\mathrm{t} \\
\text { Innovati } \\
\text { on }\end{array}$ & $\begin{array}{l}1.0 \\
60 \\
0.7 \\
62\end{array}$ & $\begin{array}{c}7.39 \\
6 \\
20.5 \\
10\end{array}$ & $\begin{array}{l}0.0 \\
00 \\
0.0 \\
00\end{array}$ & $\begin{array}{l}420 . \\
643\end{array}$ & $\begin{array}{c}0.00 \\
0\end{array}$ & $\begin{array}{l}0.5 \\
16\end{array}$ \\
\hline $\begin{array}{c}\text { DependentV } \\
\text { ariable }\end{array}$ & $\begin{array}{c}\text { Indepe } \\
\text { ndent } \\
\text { Variabl } \\
\text { e }\end{array}$ & $\overline{\mathbf{B}}$ & $\bar{t}$ & $\bar{p}$ & $\bar{F}$ & $\begin{array}{l}\text { Mo } \\
\text { del } \\
\text { (p) }\end{array}$ & $\overline{\mathbf{R}^{2}}$ \\
\hline $\begin{array}{c}\text { Brand } \\
\text { Loyalty }\end{array}$ & $\begin{array}{c}\text { Constan } \\
\mathrm{t} \\
\text { Innovati } \\
\text { on }\end{array}$ & $\begin{array}{l}0.8 \\
89 \\
0.8 \\
34\end{array}$ & $\begin{array}{c}6.18 \\
8 \\
22.4 \\
11\end{array}$ & $\begin{array}{l}0.0 \\
00 \\
0.0 \\
00\end{array}$ & $\begin{array}{l}502 . \\
238\end{array}$ & $\begin{array}{c}0.00 \\
0\end{array}$ & $\begin{array}{c}0.5 \\
60\end{array}$ \\
\hline
\end{tabular}

According to Table 7, the regression analysis that was conducted in order to find the relationship between innovation and brand trust was figured as statistically meaningful $(\mathrm{F}=351.567 ; \mathrm{p}=0.000<0.05)$. The relationship of brand trust with innovation variable, in other words, its explaining power is figured as very strong $\left(\mathrm{R}^{2}=0.471\right)$. According to this finding, the innovation level increases the level of the brand trust of the users $(\beta=0.775)$. So, the $\mathrm{H} 1$ hypothesis is confirmed.

The regression analysis that was conducted in order to find the relationship between innovation and customer satisfaction was also found as statistically meaningful ( $\mathrm{F}=420.643$; $\mathrm{p}=0.000<0.05)$. The explanatory power of the relationship between innovation and customer satisfaction is figured as very strong since $\mathrm{R}^{2}=0.516$. The increase in the innovation will also increase the customer satisfaction level $(\beta=0.762)$. So the $\mathrm{H} 2$ hypothesis is confirmed.

The result of the regression analysis also showed that the relationship between innovation and brand loyalty is meaningful $(\mathrm{F}=502.238$; $\mathrm{p}=0.000<0.05)$. The $\mathrm{R}^{2}$ value equaled 0.560 , which shows that the explaining power of the variables is very high. According to this finding, the innovation level increases the brand loyalty level $(\beta=0.834)$. So, the H3 hypothesis is also confirmed.

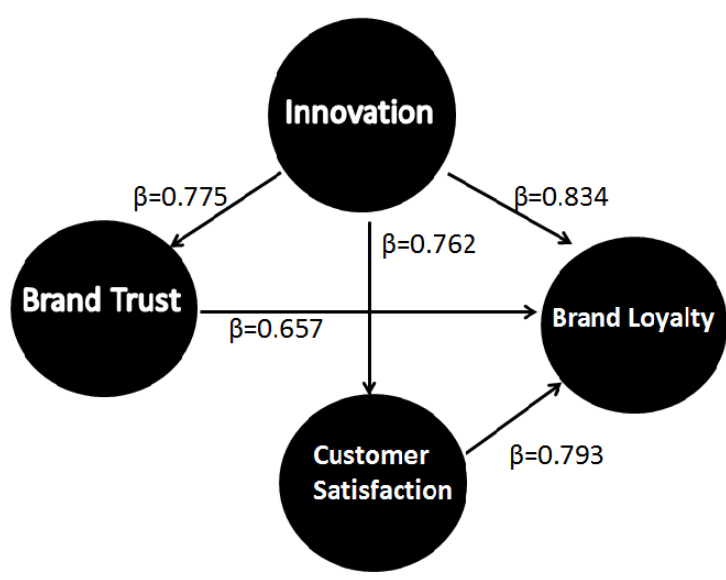

Figure 3. The Impact of Innovation on

Brand Trust, Customer Satisfaction and Brand Loyalty

According to the above figure, the beta value is describing that, if innovation changes one unit, the brand trust will change 0.775 percent, the customer satisfaction will change 0.762 percent and the brand loyalty will change 0.834 percent. Also according to the above figure, beta value in between brand trust and brand loyalty is 0.657 , which means that if brand trust increases one unit, then brand loyalty will increase 0.657 percent. Furthermore, if customer satisfaction changes one unit, then brand loyalty will increase 0.793 percent. According to this result, all five hypothesises are confirmed.

\section{Conclusion}

In this research, global online entrepreneurship concept is evaluated in terms of its relativity to innovation through literature review and through a conducted survey, it is confirmed that innovation has a positive impact on brand trust, customer satisfaction and brand loyalty within the context of service innovations. According to the results of this survey, it is observed that a global online entrepreneur like Google, which embraces innovation as a positioning strategy, also increases the brand trust, customer satisfaction and brand loyalty of the users through its innovations in the information communication technology field. Considering the research conducted, a very limited number of researches exist regarding the impact of innovation on brand trust, customer satisfaction and brand loyalty. New research need to be done on the impact of innovation on brand trust, customer satisfaction, brand image, perceived quality and customer expectations. 


\section{REFERENCES}

Aaker, D. A. 1991. Managing Brand Equity, N.Y.:

Free Press.

Aldrich H.E. and Martinez, M. 2003

"Entrepreneurship as Social Construction: A Multi-Level Evolutionary Approach', in Z.J. Acs and D.B. Audretsch (eds.), Handbook of Entrepreneurship Research: A Multidisciplinary Survey and Introduction, Boston, MA: Kluwer Academic Publishers.

Anderson E. W. and Sullivan, M.W. 1993. "The antecedents and consequences of customer satisfaction for firms", Marketing Science, 12(2):125-143.

Aydin, G. 2009. "Marka Değeri ve Finansal Performans ITU Shortened Phd Thesis, Istanbul Sanayi Odas1: ISO 2009/11.

Bell J. and Loane, S. 2010. “'New-wave' global firms: Web 2.0 and $\quad$ SME internationalization," Journal of Marketing Management, 26(3/4):213-229.

Bearden, O.W. and Teel, J. E. 1983. "Selected Determinants of Consumer Satisfaction and Complaint Reports," Journal of Marketing Research, 20(1):.21-28.

Bolton, R. N. and Drew, J. H. 1991. "A Multi-Stage Model of Customers' Assessments of Service Quality and Value," Journal of Consumer Research, 17(4):375-384.
Bozkurt, I. 2003. "Müşteri İlişkileri Yönetimi ve Perakende Sektöründe Bir Uygulama,“ Masters Thesis, YTU, SBE

Business Decisions Limited, (May 2003), "The Power of Customers to Drive Innovation: A report by Business Decisions Limited for the Enterprise Directorate General of the European Commission," Available at: $\mathrm{ftp}: / / \mathrm{ftp}$. cordis.europa.eu/pub/innovatio

n-

policy/studies/studies_the_power_of_cu stomers_to_drive_innovation.pdf (accessed 16.12.2014).

Caceres R.C. and Paparoidamis, N.G. 2007. "Service quality, relationship satisfaction, trust, commitment and business-to-business loyalty," European Journal of Marketing, 41(7/8):836-867.

Carrier, C. Raymond L. and Eltaif, A. 2004. "Cyberentrepreneurship: A multiple case study,” International Journal of Entreprenurial Behavior \& Reasearch, 10(5):349-363

Colton, D. A., Roth, M. S., and Bearden, W. O. 2010. "Drivers of International E-Tail Performance: The Complexities of Orientations and Resources," Journal of International Marketing, 18(1):1-22. 
Delgado-Ballester, E. 2003. "Development and Validation of a Brand Trust Scale,” Journal of Market Research, 13(1):1-28.

Delgado-Ballester, E., Munuera-Aleman, J.L. and Yagüe-Guillen, M.J. 2003. "Development and Validation of a Brand Trust Scale", International Journal of Market Research, 45(1):35-53

Doney, P.M. and Cannon, J.P. (1997), "An Examination of the Nature of Trust in Buyer-Seller Relationships," Journal of Marketing, 61(4):35-51.

European Commission, 2012. Guidebook Series: How to Support SME Policy from Structural Funds: The Smart Guide to Service Innovation, European Union,Belgium. Available at: http://ec.europa.eu/enterprise/policies/s me/regional-sme policies/documents/no.4_service_innov ation_en.pdf (accessed 12.10.2014).

F. Zhao (ed.) 2008. "Information Technology Entrepreneurship and Innovation," in Information Science Reference, PA, USA, 159-160.

Fournier, S. 1998. "Consumers and Their Brands: Developing Relationship Theory in Consumer Research,” Journal of Consumer Research, 24(4):343-373.
Ghafoor, M. M., Iqbal, H. K., Tariq, U. and Murtaza, F. 2012. "The Impact of Customer Satisfaction and Brand Image on Brand Loyalty," Progress in Business Innovation \& Technology Management, 2(2):69-77.

Gopalakrishnan S. and Damanpour F. 1997.

"Review of Innovation Research in Economies, Sociology and Technology Management," Omega Int. J. Mgmt. 25(11):15-28.

Hausman, J. 1995. "Competition in Long-Distance and Telecommunications Equipment Markets: Effects of the MFJ," Managerial and Decision Economics 16(4):365-383

Hisrich, R.D., Peters, M.P. and Shepherd, D.A. 2005. Entrepreneurship. New York: McGraw-Hill Irwin.

Houghton, K. A. and Winklhofer, H. 2004. "The Effect of Website and E-Commerce Adoption on the Relationship between SMEs and their Export Intermediaries," International Small Business Journal, 22(4):369-388. 
Hussain, M., Munir, A. and Siddiqui, M. 2012. "Impact of Innovation in FMCG products on customer loyalty and satisfaction: A case study of Confectionary Producer "English Biscuit Manufacturers" in Pakistan, Interdisciplinary Journal of Contemporary Research in Business , 4(8):4-23.

Jaw, Y-L. and Chang, S-H.2006. "The Internationalization of Born Globals: Entrepreneurship, Internet, and Entry Strategies," The Journal of Global Business Management, 2(2): 1-7.

Morino, M. 1999. "Netpreneurs: a new breed of entrepreneur," E-Commerce, May.

Netmarketshare.com. 2014. "Marketshare Statistics for Internet Technologies," http://www.netmarketshare.com/searchengine-marketshare. aspx ?qprid $=4 \& q p$ customd $=0$ (accessed 24.11.2014).

Schumpeter, J. A. 1934 (2008). The Theory of Economic Development: An Inquiry into Profits, Capital, Credit, Interest and the Business Cycle, translated from the German by Redvers Opie, London: Transaction Publishers.
Smith, C. 2014. "By the Numbers: 58 Amazing Amazon statistics," available at: expandedramblings.com/index.php/amazonstatistics/ (accessed:20.11.2014).

Kitchul J. and Gundry, L.K. 2002. "Prospecting for strategic advantage: the proactive entrepreneurial personality and small firm innovation," Journal of Small Business Management, 40(2):85-97.

Knight, G. A. and Cavusgil, S. T. 2004. "Innovation, organizational capabilities, and the bornglobal firm," Journal of International Business Studies, 35(2):124-141.

Lau, G.T. and Lee, S.H. 1999. "Consumers' Trust in a Brand and the Link to Brand Loyalty," Journal of Marked Focused Management, 4(4):341-370.

Lin H. and Wang, Y. 2006. "An examination of the determinants of customer loyalty in mobile commerce contexts," Information \& Management, 43(3):271-282.

McDougall, P.P. and Oviatt, B. M. 2000. "International entrepreneurship: the intersection of two research paths. "Academy of Management Journal, 43(5):902-906. 
Mostafa, H. A. R., Wheeler, C., and Jones, M. V. 2006. "Entrepreneurial orientation, commitment to the internet and export performance in small and medium sized exporting firms," Journal of International Entrepreneurship, 3(4): 291-302.

Naveed, T. Akhtar, I. and Cheema, K. 2013. "The Impact of Innovation on Customer Satisfaction and Brand Loyalty: A Study of the Students of Faisalabad, "International Journal of Management and Organizational Studies, 2(2):62-68.

OECD and Eurostat, 2005. "Oslo Manual: Guidelines for Collecting and Interpreting Innovation Data", 3rd ed. Available at: http://www.oecd.org/science/inno/oslo manualguidelinesforcollectingandinterp retinginnovationdata3rdedition.htm

Oliver, R. 1999. "Whence Consumer Loyalty?" Journal of Marketing, 63(Special Issue): 3344.

Schickler, E. 1994. "Democratizing Technology: Hierarchy and Innovation in Public Life," Palgrave Macmillan Journals, 27(2): 175199.

Simsek G.G. and Noyan, F. 2009. “Turkiye'de cep telefonu cihazi pazarinda marka sadakati icin bir model denemesi," ODTU Gelisme Dergisi, 36(1): 121-159.
Sreenivasulu M. and Rajasekhar, M. 2014. “Customer Satisfaction and Brand Loyalty towards Corporate Retail Store-[A Case Study of Big Bazaar Retail Store in Banglore City]," IOSR Journal of Economics and Finance, 16(4):1-8.

Thomas M. and Reubar, R. "Global Online Entrepreneurship: Past Research and Future Directions," Univeristy of Glasgow. Adam Smith working paper series 2013:04 available at: http://www.gla.ac.uk/media/media_278 200_en.pdf (accessed 24.10.2014).

Turk, M. 2005. "Perakendeci İşletmelerde Personelin Davranışsal Özellikleri ile Müşteri Memnuniyeti Arasındaki İlişki”, Süleyman Demirel Üniversitesi İktisadi Bilimler Fakültesi Dergisi, 10(1): 195-219.

Turker, G.O. and Turker, A. 2013. "GSM Operatorleri Sektorunde Marka Sadakatini Etkileyen Faktorlerin Belirlenmesi; Universite Ogrencileri Uzerine Bir Uygulama," Electronic Journal of Vocational Colleges, 3(1):49-67.

Upamannyu, N.K. Gulati C. and Mathur G. 2014. "Effect of Brand Trust, Brand Image on Consumer Loyalty in FCMG Sectorat Gwalior Region," Scholars Worl-IRMJCR, 2(2): 83-93. 
Urban, G.L., Sultan, F. and Qualls, W. 2000.

"Placing Trust at the Center of Your Internet

Strategy," Sloan Management Review,

42(1):39-48.

Uztug, F. 2003. Markan Kadar Konus, Istanbul:

Mediacat.

\section{Appendix A. Survey items used in the study}

\section{Brand Trust}

T1: I completely trust the search engine that I use.

T2: The search engine that I use gives me the best service.

T3: I believe that the search engine that I use will not disappoint me.

T4: Even the name of the search engine that I use guarantees that I will be satisfied with the service.

T5:The search engine that I use entirely takes care of my needs.

Customer satisfaction

S1: I am satisfied with the service the search engine that I use.

S2: The search engine that I use is successful.

S3: The search engine that I use has met my expectations.

Brand Loyalty

L1: The search engine that I use will be my first choice.

L2: I also recommend this search engine to other people.

L3: I think I am a loyal customer of this search engine.

L4: I intend to keep using this search engine.

Innovation

I1: The search engine that I use constantly provides new services.

I2: The search engine that I use is environment friendly.

I3: The search engine that I use preserves its popularity.

I4: The search engine that I use increases its service quality.

I5: The search engine that I use decreases time loss.

I6: The search engine that I use has brought new standards to the market with innovative projects. 